\title{
PENGARUH TERAPI KOGNITIF TERHADAP PENINGKATAN HARGA DIRI PASIEN GAGAL GINJAL KRONIK DI RSU KABUPATEN TANGERANG
}

\author{
Lailatul Fadilah ${ }^{1}$ \\ ${ }^{1}$ Jurusan Keperawatan Tangerang Politeknik Kesehatan Kemenkes Banten
}

\begin{abstract}
Abstrak
Perubahan yang terjadi akibat penyakit gagal ginjal memiliki dampak terhadap aspek biologis, psikologis, sosial, dan spiritual. Perubahan ini memberikan perasaan tidak berdaya dan tidak mampu karena kelemahan atau keterbatasan fisik yang dialaminya, sehingga pasien merasa malu/ minder, enggan untuk bertemu dengan orang lain, menarik diri dari lingkungan sosial. bila pasien tidak memiliki mekanisme koping dan sumber koping yang adekuat, maka dapat mengakibatkan pasien mengalami harga diri rendah, dimana hal ini dapat memperburuk kondisi kesehatan dan menurunkan kualitas hidupnya. Stuart \& Laraia, (2005) menyatakan terapi yang dapat diberikan pada pasien dengan harga diri rendah adalah terapi individu seperti terapi perilaku, terapi kognitif, terapi kognitif dan perilaku (CBT). Terapi kognitif merupakan suatu terapi yang dapat mengidentifikasi pemikiranpemikiran yang negatif yang mendorong terjadinya perubahan harga diri (Granfa, 2007). . Tujuan penelitian ini adalah Mengidentifikasi Pengaruh terapi Kognitif terhadap Peningkatan harga diri pasien dengan GGK di Ruang Hemodialisa RSU Kabupaten Tangerang. Sampel penelitian berjumlah 23 responden yaitu pasien GGK yang menjalani hemodialisa yang mengalami harga diri rendah dengan teknik consecutive sampling. Analisa yang digunakan yaitu analisa univariat dan analisa bivariat menggunakan uji $\mathrm{t}$ - dependent dengan tingkat kemaknaan $(\alpha=0,05)$. Hasil penelitian menunjukkan bahwa pada kelompok sebelum dan sesudah dilakukan terapi kognitif dengan kata lain ada perbedaan yang signifikan bahwa terapi kognitif dapat meningkatkan rata- rata kecenderungan peningkatan harga diri pada pasien GGK kelompok intervensi sebesar 6,78 ( $p$ value $=0,000$ dengan $\alpha=0,05$ ).
\end{abstract}

\section{Kata Kunci: Harga Diri Rendah, Terapi Kognitif, GGK, Hemodialisa}

Korespondensi: Lailatul Fadilah, E-mail: neng.dhilah@gmail.com

\section{PENDAHULUAN}

Perubahan yang terjadi akibat penyakit gagal ginjal memiliki dampak terhadap aspek biologis, psikologis, sosial, dan spiritual. Pasien akan mengalami masalah psikologi yang berkaitan dengan harga dirinya, karena harus memikirkan penyakitnya, sekaligus memikirkan keluarganya yang harus mencari biaya pengobatan, sehingga pada akhirnya pasien mungkin akan mengalami kesulitan dalam penerimaan diri terhadap penyakit gagal ginjal yang dideritanya. Perubahan fisik dapat menyebabkan pasien mengalami 40 
kelemahan, tidak mampu melakukan aktifitas seperti sebelum dia mengalami penyakit tersebut. Kondisi ini memberikan perasaan tidak berdaya dan tidak mampu karena kelemahan atau keterbatasan fisik yang dialaminya, sehingga pasien merasa malu/ minder, enggan untuk bertemu dengan orang lain, menarik diri dari lingkungan sosial. bila pasien tidak memiliki mekanisme koping dan sumber koping yang adekuat, maka dapat mengakibatkan pasien mengalami harga diri rendah, dimana hal ini dapat memperburuk kondisi kesehatan dan menurunkan kualitas hidupnya.

Stuart \& Laraia, (2005) menyatakan terapi yang dapat diberikan pada pasien dengan harga diri rendah adalah terapi individu seperti terapi perilaku, terapi kognitif, terapi kognitif dan perilaku (CBT). Terapi kognitif merupakan suatu terapi yang dapat mengidentifikasi pemikiran-pemikiran yang negatif yang mendorong terjadinya perubahan harga diri (Granfa, 2007). Nevid, Rathus, dan Greene, (2006) menjelaskan bahwa terapi kognitif efektif untuk mengatasi klien yang memiliki emosi negatif seperti ansietas dan depresi yang disebabkan oleh interpretasi yang keliru terhadap peristiwa-peristiwa yang mengganggu yang tidak berasal dari peristiwa-peristiwa mereka sendiri, jadi terapi kognitif efektif mengatasi mampu mengalami masalah depresi dan ansietas serta meningkatkan harga diri klien.

Terapi kognitif juga fokus untuk membantu klien mengidentifikasi dan mengkoreksi pikiran maladaptif, jenis pikiran otomatis, dan mengubah perilaku sendiri yang disebabkan oleh berbagai masalah-masalah emosional Beck, dkk (1987); Townsend mengungkapkan tujuan dari terapi kognitif adalah sebagai monitor pikiran otomatis negatif, mengetahui hubungan antara pikiran, perasaan dan perilaku, mengubah penalaran yang salah menjadi penalaran yang logis, dan membantu pasien mengidentifikasi dan mengubah kepercayaan yang salah sebagai pengalaman negatif internal pasien. Rupke, Blecke dan Renfrow (2006) menyatakan bahwa terapi kognitif efektif untuk mengatasi depresi dan memiliki efektifitas yang sama dengan antidepresan dan terapi interpersonal atau psikodinamik, kombinasi terapi kognitif dengan antidepresan sangat efektif untuk mengatasi depresi kronik. Terapi kognitif juga bagus digunakan untuk pasien yang mempunyai masalah respon parsial pada terapi antidepresan yang adekuat, dan juga efektif diberikan pada remaja yang mengalami depresi. Penelitian yang terkait dengan terapi kognitif salah satunya adalah Kristyaningsih (2009), mendapatkan 
hasil adanya perbedaan yang bermakna tingkat harga diri sebelum dan sesudah pemberian terapi kognitif. Hasil penelitian ini menunjukkan bahwa terapi kognitif bermanfaat pada pasien gagal ginjal kronik yang mengalami harga diri rendah.

Penjelasan diatas melatar belakangi peneliti untuk melakukan penelitian dengan judul “ Pengaruh terapi kognitif terhadap peningkatan harga diri pasien gagal ginjal kronik di RSU Kabupaten Tangerang Tahun 2016.”

\section{Tujuan Penelitian}

Mengidentifikasi Pengaruh terapi Kognitif terhadap Peningkatan harga diri pasien dengan GGK di Ruang Hemodialisa RSU Kabupaten Tangerang tahun 2016.

\section{Metode Penelitian}

Penelitian ini merupakan penelitian kuantitatif dengan menggunakan Desain kuasi-eksperimen dalam penelitian menggunakan one group dengan pre dan post test. Data dianalisis menggunakan analisis univariat dan bivariat. Sampel penelitian berjumlah 23 responden, tehnik pengumpulan data yang digunakan adalah consecutive sampling. Alat pengumpulan data berupa kuesioner Analisa yang digunakan yaitu analisa univariat dan analisa bivariat menggunakan uji t-test dependent dengan tingkat kemaknaan $(\alpha=0,05)$.

\section{Hasil Penelitian}

1. Distribusi rerata frekuensi kecenderungan peningkatan harga diri pada kelompok intervensi sebelum dan sesudah dilakukan terapi kognitif

Tabel 1

Distribusi rerata frekuensi kecenderungan peningkatan harga diri pada kelompok intervensi sebelum dan sesudah dilakukan terapi kognitif pada pasien GGK di Ruang Hemodialisa RSU

Kabupaten Tangerang Tahun 2016

\begin{tabular}{ccc}
\hline \hline \multicolumn{3}{c}{ Kelompok Intervensi } \\
\hline & Pre test & Post test \\
\hline Mean & 21,61 & 28.39 \\
SD & 1.118 & 1.076 \\
Minimal & 19 & 27 \\
Maksimal & 23 & 31 \\
\hline \hline
\end{tabular}

Table 1 menunjukkan bahwa nilai rerata kecenderungan peningkatan harga diri pada kelompok intervensi sebelum dilakukan terapi kognitif adalah 21,61 sedangkan setelah dilakukan terapi kogntitf nilai rerata menjadi 28,39. Sehingga terjadi peningkatan pada nilai rerata sebelum dan sesudah dilakan intervensi. Nilai minimal yang diperoleh pada kelompok intervensi sebelum dilakukan terapi kognitif adalah 
19 dan nilai setelah dilakukan terapi kognitif adalah 27. Nilai maksimal sebelum dilakukan terapi kognitif pada kelompok intervensi adalah 23 dan setelah dilakukan terapi kognitif adalah 31.

2. Diagram distribusi rerata frekuensi kecenderungan harga diri pada kelompok intervensi sebelum dan sesudah dilakukan intervensi

Table 2

Diagram distribusi rerata frekuensi kecenderungan harga diri pada kelompok intervensi sebelum dan sesudah dilakukan intervensi pada pasien GGK di Ruang Hemodialisa RSU

Kabupaten Tangerang Tahun 2016

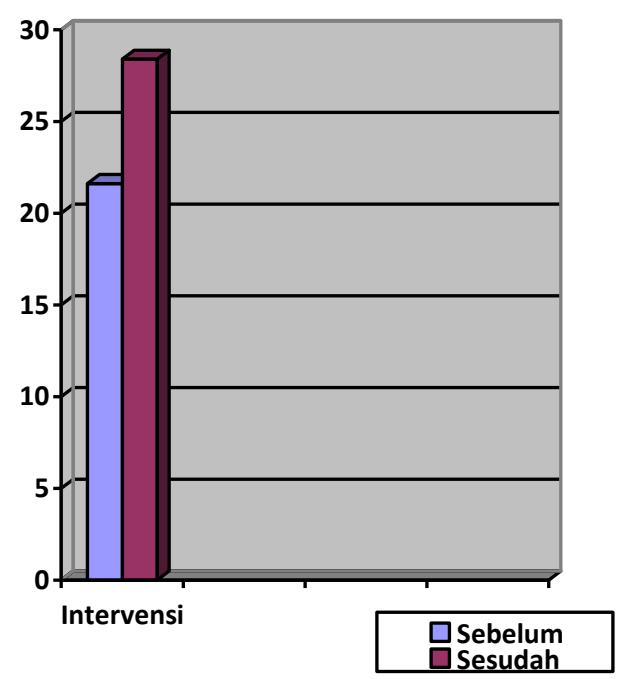

3. Distribusi rerata tingkat kecenderungan peningkatan harga diri pada kelompok intervensi sebelum dan sesudah dilakukan terapi kognitif
Tabel 3

Distribusi rerata tingkat kecenderungan peningkatan harga diri pada kelompok intervensi sebelum dan sesudah dilakukan terapi kognitif pada pasien GGK di Ruang Hemodialisa RSU Kabupaten Tangerang Tahun 2016

\begin{tabular}{lllllll}
\hline \hline Variabe & Kelom & Mean & SD & df & $t$ & $p$ \\
1 & pok & & & & & \\
& & & & & &
\end{tabular}

\begin{tabular}{|c|c|c|c|c|c|c|}
\hline \multicolumn{7}{|c|}{ Kecenderungan peningkatan harga diri } \\
\hline Interve & Sebelu & 21,61 & 1.11 & 22 & - & 0.000 \\
\hline \multirow[t]{9}{*}{ nsi } & $\mathrm{m}$ & & 8 & & 2 & \\
\hline & & & & & 2. & \\
\hline & & & & & 0 & \\
\hline & & & & & 4 & \\
\hline & & & & & 2 & \\
\hline & Sesuda & 28,39 & 1.07 & & & \\
\hline & $\mathrm{h}$ & & 6 & & & \\
\hline & Perbed & 6,78 & 0.04 & & & \\
\hline & aan & & 2 & & & \\
\hline
\end{tabular}

Keterangan : bermakna/signifikan pada $\alpha=0,05$

Table 3 menunjukkan rata - rata kecenderungan peningkatan harga diri pada pasien GGK yang menjalani hemodialisa di ruang hemodialisa RSU Kabupaten Tangerang setelah dilakukan terapi kognitif pada kelompok intervensi adalah 21,61 dengan standar deviasi 1.118 dan setelah dilakukan terapo kognitif adalah 28,39 dengan standar deviasi 1.076. Analisa lebih lanjut 
adanya perbedaan bermakna antara kecenderungan peningkatan harga diri pada pasien GGK yang menjalani hemodialisa di ruang hemodialisa RSU Kabupaten Tangerang pada kelompok sebelum dan sesudah dilakukan terapi kognitif dengan kata lain ada perbedaan yang signifikan bahwa terapi kognitif dapat meningkatkan rata- rata kecenderungan peningkatan harga diri pada pasien GGK kelompok intervensi sebesar 6,78 ( $\mathrm{p}$ value $=0,000$ dengan $\alpha$ $=0,05)$.

\section{Pembahasan}

Kecenderungan peningkatan harga diri sebelum dan setelah dilakukan terapi kognitif pada pasien GGK yang menjalani terapi hemodialisa pada kelompok intervensi menunjukkan ada peningkatan harga diri pada kelompok intervensi. Hal ini dapat dilihat dari nilai rerata pada kelompok intervensi sebelum dilakukan terapi kognitif yaitu 21,61 dan setelah dilakukan terapi kognitif nilai rerata kelompok intervensi adalah 28,39. Analisa lebih lanjut adanya perbedaan yang bermakna antara kecenderungan peningkatan harga diri pada pasien GGK yang menjalani hemodialisa, bahwa terapi kognitif dapat meningkatkan rerata harga diri pada pasien GGK yang menjalani Hemodialisa sebesar 6,78 (p value $=$ 0,000 dengan $\alpha=0,05$ ).

Jurnal Medikes, Volume 5, Edisi 1, April 2018
Terapi kognitif dilakukan setelah responden mengisi kuesioner harga diri dan dinyatakan mengalami harga diri rendah. Dan setelah dilakukan terapi kognitif responden mengisi kembali kuesioner harga diri dan kemudian diinterpretasi hasilnya. Terapi kognitif yang diberikan pada kelompok intervensi terdiri dari 4 sesi, dimana tahapan pertama adalah Mengidentifikasi pikiran otomatis negatif dan penggunaan tanggapan rasional terhadap pikiran negatif yang pertama. Sesi kedua adalah penggunaan tanggapan rasional terhadap pikiran negatif yang kedua. Sesi ketiga adalah mengidentifikasi manfaat tanggapan rasional terhadap pikiran otomatis negatif (ungkapan hasil dalam mengikuti terapi kognitif). Sesi terakhir adalah melibatkan keluarga untuk dapat membantu pasien dalam melakukan terapi kognitif secara mandiri. Terapi kognitif dilakukan secara individu, dimana setiap responden mendapatka terapi kognitif sebanayak 4 sesi.

Kecenderungan peningkatan harga diri pada pasien GGK yang menjalani hemodialisa sesuai dengan teori yang dikemukakan oleh Stuart \& Laraia, (2005) menyatakan terapi yang dapat diberikan pada pasien dengan harga diri rendah adalah terapi individu seperti terapi perilaku, terapi kognitif, terapi kognitif dan perilaku (CBT). Terapi 
kognitif merupakan suatu terapi yang dapat mengidentifikasi pemikiranpemikiran yang negatif yang mendorong terjadinya perubahan harga diri (Granfa, 2007). Nevid, Rathus, dan Greene, (2006) menjelaskan bahwa terapi kognitif efektif untuk mengatasi klien yang memiliki emosi negatif seperti ansietas dan depresi yang disebabkan oleh interpretasi yang keliru terhadap peristiwa-peristiwa yang mengganggu yang tidak berasal dari peristiwaperistiwa mereka sendiri, jadi terapi kognitif efektif mengatasi mampu mengalami masalah depresi dan ansietas serta meningkatkan harga diri klien.

Terapi kognitif juga fokus untuk membantu klien mengidentifikasi dan mengkoreksi pikiran maladaptif, jenis pikiran otomatis, dan mengubah perilaku sendiri yang disebabkan oleh berbagai masalah-masalah emosional Beck, dkk (1987); Townsend mengungkapkan tujuan dari terapi kognitif adalah sebagai monitor pikiran otomatis negatif, mengetahui hubungan antara pikiran, perasaan dan perilaku, mengubah penalaran yang salah menjadi penalaran yang logis, dan membantu pasien mengidentifikasi dan mengubah kepercayaan yang salah sebagai pengalaman negatif internal pasien. Rupke, Blecke dan Renfrow (2006) menyatakan bahwa terapi kognitif efektif untuk mengatasi depresi dan memiliki efektifitas yang sama dengan antidepresan dan terapi interpersonal atau psikodinamik, kombinasi terapi kognitif dengan antidepresan sangat efektif untuk mengatasi depresi kronik. Terapi kognitif juga bagus digunakan untuk pasien yang mempunyai masalah respon parsial pada terapi antidepresan yang adekuat, dan juga efektif diberikan pada remaja yang mengalami depresi.

Penelitian yang terkait dengan terapi kognitif salah satunya adalah Kristyaningsih (2009), mendapatkan hasil adanya perbedaan yang bermakna tingkat harga diri sebelum dan sesudah pemberian terapi kognitif. Hasil penelitian ini menunjukkan bahwa terapi kognitif bermanfaat pada pasien gagal ginjal kronik yang mengalami harga diri rendah.

\section{Kesimpulan}

1. Kecenderungan rerata peningkatan harga diri pada kelompok intervensi sebelum dilakukan terapi kognitif adalah 21,61, sedangkan setelah dilakukan terapi kognitif pada kelompok intervensi hasilnya adalah 28,39. Sedangkan standar deviasi sebelu dilakukan intervensi adalah 1.118 dan setelah intervensi sebesar 1.076 .

2. Ada perbedaan bermakna antara kecenderungan peningkatan harga diri pada pasien GGK yang 
menjalani hemodialisa di ruang hemodialisa RSU Kabupaten Tangerang pada kelompok sebelum dan sesudah dilakukan terapi kognitif dengan kata lain ada perbedaan yang signifikan bahwa terapi kognitif dapat meningkatkan rata- rata kecenderungan peningkatan harga diri pada pasien GGK kelompok intervensi sebesar 6,78 ( $\mathrm{p}$ value $=0,000$ dengan $\alpha=$ $0,05)$.

\section{Saran}

1. Perawat

Untuk meningkatkan harga diri pasien GGK yang menjalani terapi hemodialisa perawat dapat mengaplikasikan terapi kognitif. Terapi kognitif bisa dijadikan sebagi suatu program bimbingan yang dilakukan secara individu bagi pasien yang dilakukan secara berkelanjutan.

2. Pasien

Pasien dapat menerapkan terapi kognitif secara mandiri, kapan dan dimana saja. Dengan terapi kognitif dapat meningkatkan penilaian pasien terhadap diri sendiri yang positif sehingga meningkatkan motivasi pasien dalam menjalani kehidupan selanjutnya.

3. Keluarga
Keluarga mempunyai peranan yang sangat penting dalam memberikan dukungan dan motivasi kepada pasien untuk melakukan terapi kognitif yang dapat meningkatkan motivasi dan harga diri pasien yang mengalami GGK.

\section{DAFTAR PUSTAKA}

Kristyaningsih, F., Keliat, B. A. Dan helena,.N. C. D. (2009) : pengaruh Terapi kognitif terhadap perubahan harga diri dan kondisi depresi pasien gagal ginjal kronik di ruang hemodialisa RSUP Fatmawati Jakarta

Greene, B., Rathus, Spencer A., Nevid, Jeffrey S. (2006). Abnormal Psychology in a Changing World. 6th ed. New Jersey: Pearson Education Inc, Upper Saddle River.

Polit, D.F \& Beck, C.T. (1999). Nursing Research : principle and methods. $6^{\text {th }}$ Ed. Philadelphia : Lippincott Williams \& Wilkins

Rupke, S.J., Blecke, D., \& Renfrow, M. (2006). Cognitive Therapy for Depression.

Stuart \& Laraia. (2005). Principles and practice of psychiatric nursing. St. Louis : Mosby 
Suddart, Brunner. 2001. Buku Ajar Keperawatan Medikal-Bedah Edisi 8 vol 2. Jakarta : EGC

Smeltzer Suzanne C, 2002, Buku Ajar Keperawatan Medikal Bedah, (Edisi 8), Vol. 2. Jakarta, EGC.

Towsend. (2005). Essentials of psychiatric mental health nursing. $3^{\text {th }}$ Ed. Philadelphia : F.A Davis Company

Varcarolis, Elizabet. M. Et al. (2006). Foundation of Pshychiatric Mental Health Nursing A Clinical Approach, Edisi 5. Sounders Elseiver. St. Louis Missouri 